Part 3 are six essays on how the development and use of new instruments change chemistry and chemical discovery. Part 5 and 6 show the reader many aspects of "Big Science" and the interface between science and industry. Part 6 ends with the fascinating story of Reatha Clark King and her work with fluorine. Part 7-"Social Activism, Sisters in Arms" ends with two essays on the uses and dangers of lead; a look at the darker side of the century of chemical discovery.

The thematic division of the book continues into the three indices at the book's end. There is an Element Index which includes old and new element names, so fire, air, earth and water are listed; a Name Index with organizational names as well people, and a General Index for everything else.

Sweden is the only country listed in the Element Index. Under Sweden are the fifteen elements discovered in this Nordic country that is the home of Alfred Nobel. Radium is the element with the most references in the index, partly because Marie Curie is the most referenced name in the Name Index. The indices are very useful and fun to browse to look for themes in the book. The International Union of Pure and Applied Chemistry is referenced six times in the Name Index.

The book could be used in many ways for those studying women in chemistry, scientific innovation, the history of discovery of elements, as well as larger themes of radioactivity, social activism and the history of science. Women in their Element brings together 38 stories over four centuries that put women at the center of the long story of discovery that takes the world from "fire, air, earth and water" to the Periodic Table of Elements in all of its complexity.

\section{For Science, King \& Country: The Life and Legacy of Henry Moseley}

\author{
Roy Macleod, Russel G. Egdell, and Elizabeth \\ Bruton (eds.) Uniform Press, 2018. 328 pp.-ISBN \\ 9783132012417
}

\section{reviewed by D. Brynn Hibbert}

Henry ("Harry") Gwin Jeffreys Moseley (1887-1915) was, or perhaps would have been, the pin-up scientist of a world entering the atomic age. In this well-produced, extensively-illustrated collection of essays coming from thirteen scholars we have "a more detailed analysis" of his life and research as promised by the editors in the preface to the book. They were prompted by the 2015 exhibition Dear Harry ... Henry
Moseley: A Scientist Lost to War at the Museum of the History of Science at Oxford [1]. Roy MacLeod, Historian of Science, and Russell Egdell, Inorganic Chemist, explain in the introduction that Moseley's brief life, but long legacy, can only be seen through the comparative lenses of history, science, and the history of science. They do justice to each of these.

In some ways the science is straightforward. With hindsight and our present knowledge of atomic structure we read Moseley's two papers The High-Frequency Spectra of the Elements published in 1913 and 1914, as nailing the concept of atomic number, which he identifies "with the number of positive units of electricity contained in the atomic nucleus". But there is still some confusion as to the exact nature of "Moseley's Law," as detailed by John Heilbron (Chapter 10), the author of the first biography of Moseley in 1974. Russell Egdell's account of "X-ray spectroscopy 100 years on" (Chapter 9 ) shows how ubiquitous $X$-rays have become with the inevitable miniaturisation leading to spectrometers in scrap yards and even in space, spawning acronyms galore (in surface analysis alone: XRF, ESCA, XPS, XAS, EXAFS, NEXAFS, SEXAFS, XANES, TXRF, PIXE [2]). As an analytical chemist, I might take up MacLeod and Egdell's assertion that “... X-ray spectroscopy did develop to become arguably the most important of all chemical analytical techniques, ...". My chromatographic and mass spectrometric colleagues might wish to argue, but we should not be so churlish, having rather few war heroes in our ranks.

To a contemporary audience the burning question must be whether Moseley would have won a Nobel Prize, and whether in Physics or Chemistry? There are several contenders and it may be unkind (to Barkla) to suggest the work of C. G. Barkla, recognised in 1918, was a "posthumous tribute to Moseley," as Robert Friedman raises in his introduction to Chapter 6 . This is a fascinating chapter that looks at the deliberations of the five-member Nobel Committee for Chemistry, augmented by the great chemist Arrhenius. In a section "Biased Neutrality" the problems of a Germany-leaning neutral country (Sweden) Friedman tells us what difficulties the Nobel Committees faced, not being able to postpone the prize in wartime. Friedman sums up "Today Henry Moseley stands as one of the greatest scientists of the past century, we do not need the award of a Nobel Prize to command our appreciation and respect."

Earlier, in Chapter 4, Eric Scerri puts Moseley in context of the work that was happening around him. Antonius van den Broek is credited with the concept of the ordering of elements on a whole number scale, and 


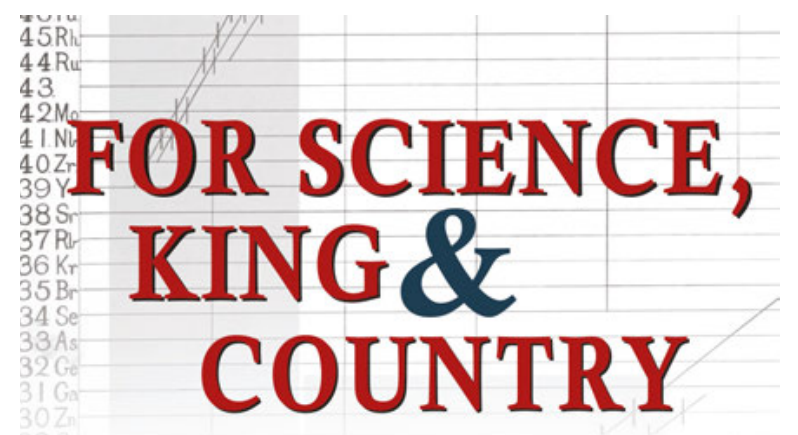

THE LIFE AND LEGACY OF HENRY MOSELEY

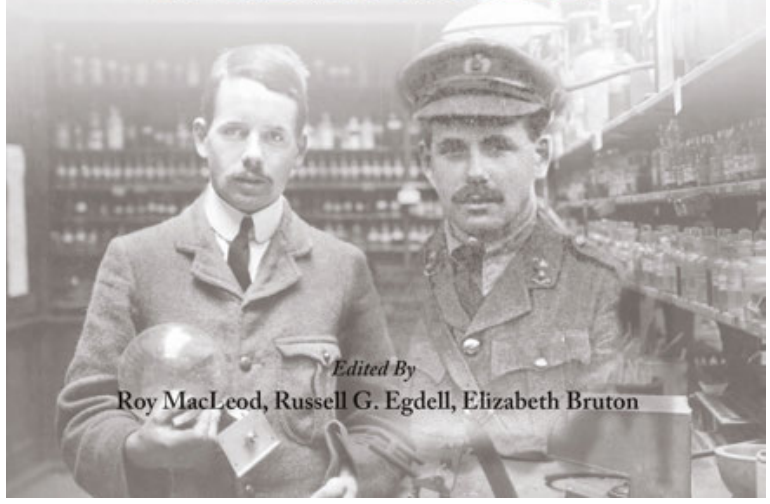

indeed, Moseley started his work with the "express purpose of verifying van den Broek's hypothesis." While van den Broek's work was flawed, it provided a vital stimulus to the understanding that was to come after. Scerri reminds us that science rarely progresses in quantum leaps by geniuses with bursts of insight that make good television, but "develops as an organic whole."

The history of his early years by Clare Hopkins (Chapter 1) in which his life at the English private school Eton, and then Oxford University paints the picture of a bright, upper middle class, Edwardian boy. Armed with a Second Class Honours degree Moseley went to Manchester where Ernest Rutherford was discovering $X$-rays, radioactivity and the "chemical atom" (Neil Todd, Chapter 2). A stock of radium meant that Rutherford's laboratory had the wherewithal to conduct the experiments that would become Moseley's legacy. Photographs of the science laboratories reminded me of my undergraduate years at King's College London from 1969. Not much had changed, so I assume they were cutting edge in 1900. However, Todd regrets that the building housing the basement in which Moseley researched, the "cradle of modern physics," has been allowed to fall into disrepair after the physics department moved to a new building in 1968.

The story of Lte. Henry Moseley, his desire to serve actively in the war, and his brief time in Gallipoli is told by Elizabeth Bruton (Chapter 5). There is unintentional irony in the reactions to Moseley's death deploring that one of England's foremost scientists should be allowed to go to the front line and be killed (send some ignorant fellow, is the inference), instead of being kept safe to work on ever better methods of waging war. Living in Australia with the landings at Gallipoli being cause for a major national holiday I was interested to read that any other troops were involved. (In fact, Australian and New Zealand troops, ANZACs, were a minority in this ill-conceived and ultimately failed attack).

The book is a reflection on the special exhibition "Dear Harry..." at the Museum of the History of Science, and concludes with a chapter by Elizabeth Bruton, Silke Ackermann and Stephen Johnston that describes the exhibition, its reception and how it told the story of Moseley the man, the scientist, the soldier, one hundred years after his death.

There is a nice link with the IUPAC community. Henry Moseley was given element 72 (hafnium) in the Periodic Table of Younger Chemists (https://iupac. org/100/pt-of-chemist/), part of the celebration of the 150 years of the modern periodic table. He was the only dead scientist, and the only physicist, and his element was the one of the four 'missing' elements identified by gaps in the frequencies of X-ray lines when plotted according to Moseley's Law. A chapter author, Kristen Frederick-Frost, who describes Moseley's diagram in the book, has also written a fascinating account of his search for element 72 in Chemistry International [3].

\section{References}

1. Dear Harry... project and special exhibition at the Museum of the History of Science, Oxford, UK; http:// www.mhs.ox.ac.uk/moseley/ (last accessed 10 August 2020, on Mosely's 105 death anniversary)

2. Takeuchi, T.; McQuillan, J.; Shard, A.; Russell, A.; Hibbert, D. B.: Glossary of Methods and Terms used in Surface Chemical Analysis (IUPAC Recommendations 2020). Pure App. Chem. in press (or if AOP add date and DOI)

3. Frederick-Frost, K. M.: Henry Moseley and the Search for Element 72, Chem Int 2019, 41(2), 23-27; https://doi. org/10.1515/ci-2019-0205 